DOI: http://doi.org/10.31617/k.knute.2019-04-12.67

Сидоренко О.В., $\partial-p$ m. н., проф. Google Scholar: https://scholar.google.com.ua/citations?user=qnhM7lcAAAAJ\&hl=uk Романенко О.В., $к$. . н., доц. Google Scholar https://scholar.google.com.ua/citations?user=r0W_TbgAAAAJ\&hl=uk Київський національний торговельно-економічний університет, м. Київ, Україна

\title{
ДИНАМІКА РЕОЛОГІЧНИХ ВЛАСТИВОСТЕЙ ПРЕСЕРВІВ З ПРІСНОВОДНОЇ ТА МОРСЬКОЇ РИБИ
}

Реологічні властивості, наряду з органолептичними та фізикохімічними, є суттєвим критерієм вибору сировини у ресторанному господарстві. Проте структурно-механічні, фізико-хімічні та органолептичні властивості суттєво відрізняються залежно від сировини та змінюються протягом усього терміну зберігання. Нестабільні значення структурно-механічних властивостей пресервів навіть одного виробника часто призводять до відмови від їх купівлі [1].

Відомо, що структурно-механічні властивості продуктів формуються під впливом змін хімічного складу та фізико-хімічних властивостей [2].

Формування структури та смаку рибних пресервів відбувається без термічної обробки, тому не завжди оцінити ступінь їх готовності та консистенцію можливо органолептичним методом [3].

Було досліджено динаміку структурно-механічних властивостей пресервів 3 прісноводної риби та оселедця,їх загальний хімічний склад. Було взято три зразки. Зразок 1 - пресерви з оселедця, зразок 2 пресерви з білого амуру, зразок 3 - пресерви з товстолобика з овочами.

3 метою визначення впливу хімічного складу на структурномеханічні властивості пресервів 3 риби було визначено їх загальний хімічний склад після 5 та 45 діб зберігання табл. 1.

Аналіз загального хімічного складу пресервів засвідчив, що вміст білку у зразках пресервів коливається від 11,9\% до 10,9\%. Після 45 діб зберігання вміст білку зменшується, найбільше це відмічено у пресервах товстолобика - на 1,8\%. Вміст жиру у готових пресервах склав від 2,29 до 3,50\%, що позитивно діє на смакові властивості продукту. 
Загальний хімічний склад рибних пресервів, $\%(n=5, p \leq 0,05)$

\begin{tabular}{|l|c|c|c|c|c|c|}
\hline \multirow{2}{*}{ Вміст } & \multicolumn{3}{|c|}{ Після 5 діб зберігання } & \multicolumn{3}{c|}{ Після 45 діб зберігання } \\
\cline { 1 - 7 } & Зразок 1 & Зразок 2 & Зразок 3 & Зразок 1 & Зразок 2 & Зразок 3 \\
\hline Вологи & $79,5 \pm 2,4$ & $80,1 \pm 2,3$ & $80,5 \pm 2,7$ & $80,2 \pm 24$ & $80,1 \pm 2,3$ & $83,8 \pm 2,6$ \\
\hline Білку & $11,9 \pm 0,8$ & $11,1 \pm 0,9$ & $10,9 \pm 0,8$ & $10,3 \pm 0,9$ & $10,1 \pm 0,9$ & $9,1 \pm 0,7$ \\
\hline Жиру & $4,18 \pm 0,21$ & $3,50 \pm 0,20$ & $3,24 \pm 0,21$ & $3,24 \pm 0,22$ & $3,21 \pm 0,26$ & $2,59 \pm 0,24$ \\
\hline Золи & $5,08 \pm 0,14$ & $5,32 \pm 0,16$ & $5,3 \pm 0,15$ & $5,25 \pm 0,17$ & $5,58 \pm 0,16$ & $5,51 \pm 0,16$ \\
\hline
\end{tabular}

Стійкість пресервів під час зберігання залежить від швидкості і глибини процесів якісних змін, що відбуваються в білковій і ліпідній фракціях продукції. Відомо, що жири риб є найменш стабільними при переробці і зберіганні. Зміни хімічного складу та активної кислотності багато в чому визначають структурно-механічні властивості продуктів переробки риби. Тому, наступним етапом було встановлення межі міцності поверхні рибних пресервів методом пенетрації (рис. 1).

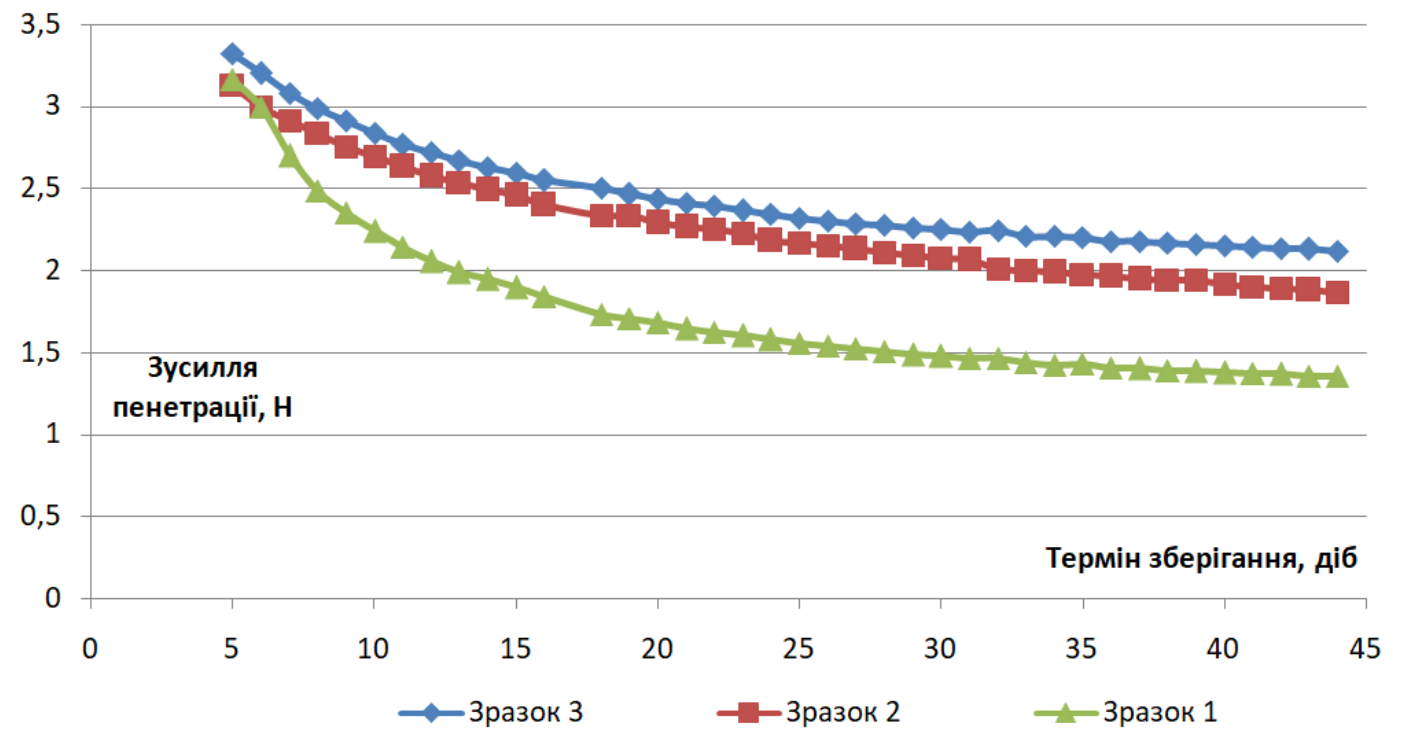

Рис. 1. Динаміка міџності поверхні зразків пресервів

На основі регресійного аналізу графіків зміни міцності поверхні зразків, встановлено динаміку зменшення міцності поверхні пресервів. Так зменшення міцності структури у пресервах з оселедця відбувається швидше на 28,3\%, ніж пресервів з білого амуру, і на $31,6 \%$ швидше, ніж у пресервах з товстолобика. Встановлено, що між структурно-механічними властивостями та активною кислотністю пресервів спостерігається зворотна залежність. 
На основі регресійного аналізу графіків зміни міцності поверхні зразків, встановлено динаміку зменшення міцності поверхні пресервів. Так зменшення міцності структури у пресервах 3 оселедця відбувається швидше на 28,3\%, ніж пресервів з білого амуру, і на 31,6\% швидше, ніж у пресервах з товстолобика.

Встановлено, що між структурно-механічними властивостями та активною кислотністю пресервів спостерігається зворотна залежність. Визначено коефіцієнти кореляції між показниками активної кислотності та межею міцності поверхні зразків пресервів. Так для пресервів з оселедця - -0,72; для пресервів 3 товстолобика $-0,65$; 3 білого амуру -0,68. Динаміка структурно-механічних властивостей пресервів 3 прісноводної риби суттєво відрізняється від динаміки релаксаційного зусилля пресервів з оселедця, зокрема пресерви з прісноводної риби мають інтенсивнішу динаміку зменшення релаксаційного зусилля у процесі зберігання, що обумовлює необхідність зберігання пресервів з прісноводної риби в твердій тарі.

\section{Список бібліографічних посилань}

1. Shapoval S.L., Romanenko O.V. Method of determining the relaxation force of fish// Scientific Messenger of LNU of Veterinary Medicine and Biotechnologies. vol. 20, no 90 P. 7-11.

2. Сидоренко О.В., Боліла Н.О., Форостяна Н.П. / Прогнозування структурних характеристик чорноморської акули катран залежно від імпульсу сили деформації //ВісникНац. техн. ун-ту «ХПІ» : зб. наук.пр. Сер. : Нові рішення в сучасних технологіях. - Харків : НТУ «ХПІ», 2016. - № 42 (1214). - С. 205-210.

3. Гуць В.С., Сидоренко О.В., Романенко О.В., Структурно-механічні властивості риборослинних продуктів. 2006. // Товари і ринки. 2006. -No 2. - C. 127-134. 